\title{
KAJIAN PERSEPSI MAHASISWA TERHADAP LINGKUNGAN FISIK UNIVERSITAS PGRI ADI BUANA SURABAYA
}

\author{
Oleh : Raja Jusmartinah *)
}

\begin{abstract}
Abstrak
Sebagai salahsatu Universitas swasta dengan jumlah mahasiswa mencapai 6000 mahasiswa, Universitas PGRI Adi Buana Surabaya telah melayani mahasiswa dari latarbelakang yang berbeda-beda sejak tahun 1971 dan terus berupaya mengembangkan sarana dan prasarana kampus dalam menciptakan suasana lingkungan yang kondusif sejalan dengan Rencana Strategis Universitas PGRI Adi Buana Surabaya.

Dalam upaya terus meningkatkan kualitas dan mutu layanan bagi mahasiswa selain meningkatkan jumlah mahasiswa baru melalui promosi dari pengalaman mahasiswa, perlu dilakukan penelitian tentang 'Kajian Persepsi Mahasiswa Terhadap Lingkungan Fisik Universitas PGRI Adi Buana Surabaya' yang mengarah pada elemen- elemen fisik yang menunjang kegiatan mahasiswa di kampus Universitas PGRI Adi Buana Surabaya. Hasil kajian ini diharapkan dapat menjadi rekomendasi bagi kebijakan dalam perencanaan dan pengembangan institusi dan lingkungan fisik berupa sarana dan prasarana.

Kajian dilakukan dengan membuat gambaran eksisting dua lokasi kampus yang ada dengan melibatkan mahasiswa Program Studi Perencanaan Wilayah dan Kota, selanjutnya dilakukan penyebaran kuesioner terhadap mahasiswa pada setiap program studi yang ada secara random sampling tentang penggunaan bangunan, bentuk bangunan, sirkulasi, ruang terbuka, penandaan dan penerangan. Dari hasil analisa data tersebut didapat bahwa secara keseluruhan mahasiswa memiliki persepsi yang cukup baik terhadap pemanfaatan ruang dan bentuk bangunan kampus, namun masih merasa kurang nyaman dalam hal sirkulasi pejalan kaki, kurangnya fasilitas ruang terbuka bagi mahasiswa serta kenyamanan fasilitas ruang yang masih belum merata.
\end{abstract}

\section{Kata Kunci : Persepsi Mahasiswa, Lingkungan Fisik Kampus, Universitas Adi Buana Surabaya}

\section{PENDAHULUAN}

Lingkungan kampus memberikan dampak pada persepsi dan perilaku, serta menjadi bagian dari pengalaman akademik yang sangat mengesankan bagi mahasiswa (Astin,1975). Berdasarkan penelitian, terdapat korelasi yang sangat berpengaruh antara mahasiswa dan pengalamannya terhadap lingkungan fisik kampus, mulai dari kedatangan pertama sekali mahasiswa ke suatu kampus, pengalaman pertama mengikuti perkuliahan dan kegiatan kemahasiswaan serta pengalamanpengalamannya selama mengikuti perkuliahan sampai pada masa akhir studi.

Dalam buku 'Educating by Design: Creating Campus Environment that Work', oleh C.Carney Strange dan James H. Baning (2001) menjelaskan bahwa terdapat aspekaspek fungsional dan simbolik yang memberikan kesan pada lingkungan sesuai dengan persepsi dan cara pandang masingmasing mahasiswa. Kesan yang ditimbulkan dari lingkungan fisik itulah yang dapat memberikan rasa nyaman dan rasa memiliki sehingga mahasiswa dapat berperan aktif dalam menciptakan atmosfer akademik di lingkungan kampus.

Bagaimana mahasiswa berinteraksi dengan lingkungan fisik kampus sangat bergantung pada latarbelakang dan pengalamannya karena perguruan tinggi merupakan lembaga pendidikan yang melayani mahasiswa yang memilki latarbelakang yang heterogen baik dari asal daerah, suku, budaya, jurusan pendidikan bahkan dari latarbelakang keluarga yang beragam (Palomba\&Banta, 1999).

Perumusan masalah dalam penelitian ini adalah :

1. Bagaimana persepsi mahasiswa terhadap kondisi eksisting lingkungan fisik kampus Universitas PGRI Adi buana Surabaya.

2. Bagaimana usulan perencanaan fisk kampus menurut persepsi mahasiswa guna meningkatkan kenyamanan lingkungan kampus Universitas PGRI Adi Buana Surabaya

*) Dosen Perencanaan Wilayah dan Kota (PWK) Universitas PGRI Adi Buana Surabaya 
Tujuan penelitian ini adalah :

Adapun tujuan dan target luaran yang ingin dicapai pada penelitian ini adalah:

1. Mendapatkan gambaran tentang persepsi mahasiswa terhadap lingkungan kampus Universitas PGRI Adi Buana Surabaya dan harapan mahasiswa terhadap pengembangannya.

2. Mendapatkan usulan konsep rancangan lingkungan fisik kampus Universitas PGRI Adi Buana Surabaya berdasarkan persepsi dan kenyamanan mahasiswa.

\section{KAJIAN PUSTAKA}

\section{Persepsi lingkungan}

Persepsi merupakan suatu proses yang didahului oleh penginderaan, yaitu suatu stimulus yang diterima oleh individu melalui alat reseptor yaitu indera. Alat indera merupakan penghubung antara individu dengan dunia luarnya. Persepsi merupakan stimulus yang diindera oleh individu, diorganisasikan kemudian diinterpretasikan sehingga individu menyadari dan mengerti tentang apa yang diindera.

$$
\text { Gibson (1989) dalam buku }
$$

Organisasi Dan Manajemen Perilaku, Struktur; memberikan definisi persepsi adalah proses kognitif yang dipergunakan oleh individu untuk menafsirkan dan memahami dunia sekitarnya (terhadap obyek). Gibson juga menjelaskan bahwa persepsi merupakan proses pemberian arti terhadap lingkungan oleh individu. Oleh karena itu, setiap individu memberikan arti kepada stimulus secara berbeda meskipun objeknya sama. Cara individu melihat situasi seringkali lebih penting daripada situasi itu sendiri.

Dari pendapat tersebut dapat disimpulkan bahwa pengertian persepsi merupakan suatu proses penginderaan, stimulus yang diterima oleh individu melalui alat indera yang kemudian diinterpretasikan sehingga individu dapat memahami dan mengerti tentang stimulus yang diterimanya tersebut. Proses menginterpretasikan stimulus ini biasanya dipengaruhi pula oleh pengalaman dan proses belajar individu.

Faktor-faktor yang mempengaruhi persepsi pada dasarnya dibagi menjadi 2 yaitu Faktor Internal dan Faktor Eksternal.

a. Faktor Internal yang mempengaruhi persepsi, yaitu faktor-faktor yang terdapat dalam diri individu, yang mencakup beberapa hal antara lain :

1) Fisiologis. Informasi masuk melalui alat indera, selanjutnya informasi yang diperoleh ini akan mempengaruhi dan melengkapi usaha untuk memberikan arti terhadap lingkungan sekitarnya. Kapasitas indera untuk mempersepsi pada tiap orang berbeda-beda sehingga interpretasi terhadap lingkungan juga dapat berbeda.

2) Perhatian. Individu memerlukan sejumlah energi yang dikeluarkan untuk memperhatikan atau memfokuskan pada bentuk fisik dan fasilitas mental yang ada pada suatu obyek. Energi tiap orang berbedabeda sehingga perhatian seseorang terhadap obyek juga berbeda dan hal ini akan mempengaruhi persepsi terhadap suatu obyek.

3) Minat. Persepsi terhadap suatu obyek bervariasi tergantung pada seberapa banyak energi atau perceptual vigilance yang digerakkan untuk mempersepsi. Perceptual vigilance merupakan kecenderungan seseorang untuk memperhatikan tipe tertentu dari stimulus atau dapat dikatakan sebagai minat.

4) Kebutuhan yang searah. Faktor ini dapat dilihat dari bagaimana kuatnya seseorang individu mencari obyekobyek atau pesan yang dapat memberikan jawaban sesuai dengan dirinya.

5) Pengalaman dan ingatan. Pengalaman dapat dikatakan tergantung pada ingatan dalam arti sejauh mana seseorang dapat mengingat kejadian-kejadian lampau untuk mengetahui suatu rangsang dalam pengertian luas.

6) Suasana hati. Keadaan emosi mempengaruhi perilaku seseorang, mood ini menunjukkan bagaimana perasaan seseorang pada waktu yang dapat mempengaruhi bagaimana seseorang dalam menerima, bereaksi dan mengingat.

b. Faktor Eksternal yang mempengaruhi persepsi, merupakan karakteristik dari linkungan dan obyek-obyek yang terlibat didalamnya. Elemen-elemen tersebut dapat mengubah sudut pandang seseorang 
terhadap dunia sekitarnya dan mempengaruhi bagaimana seseoarang merasakannya atau menerimanya. Sementara itu faktor-faktor eksternal yang mempengaruhi persepsi adalah :

1) Ukuran dan penempatan dari obyek atau stimulus. Faktor ini menyatakan bahwa semakin besrnya hubungan suatu obyek, maka semakin mudah untuk dipahami. Bentuk ini akan mempengaruhi persepsi individu dan dengan melihat bentuk ukuran suatu obyek individu akan mudah untuk perhatian pada gilirannya membentuk persepsi.

2) Warna dari obyek-obyek. Obyekobyek yang mempunyai cahaya lebih banyak, akan lebih mudah dipahami (to be perceived) dibandingkan dengan yang sedikit.

3) Keunikan dan kekontrasan stimulus. Stimulus luar yang penampilannya dengan latarbelakang dan sekelilingnya yang sama sekali di luar sangkaan individu yang lain akan banyak menarik perhatian.

4) Intensitas dan kekuatan dari stimulus. Stimulus dari luar akan memberi makna lebih bila lebih sering diperhatikan dibandingkan dengan yang hanya sekali dilihat. Kekuatan dari stimulus merupakan daya dari suatu obyek yang bisa mempengaruhi persepsi.

5) Motion atau gerakan. Individu akan banyak memberikan perhatian terhadap obyek yang memberikan gerakan dalam jangkauan pandangan dibandingkan obyek yang diam.

\section{Peranan Lingkungan Fisik terhadap Perilaku.}

Hubungan antara lingkungan fisik dan pemakai merupakan suatu hubungan timbal balik yang saling mengisi. Disatu pihak lingkungan fisik dapat membentuk karakter pemakainya seperti apa yang diinginkan perancang, namun dipihak lain terbentuknya karakter suatu lingkungan fisik juga dapat ditimbulkan akibat perilaku pemakainya. Sehingga dikatakan bahwa hal yang terpenting adalah bagaimana orang menanggapi suatu produk bangunan maupun lingkungan fisik, karena walau bagaimanapun kesan atau karakter suatu bangunan sama pentingnya dengan bangunan itu sendiri, seperti dikatakan Churchill (dalam Halim, 2005) bahwa "kita membentuk bangunan kita dan kemudian bangunan kita-lah yang membentuk kita (we give shape to our buildings and they, in turn shape us)"

Perencanaan fasilitas merupakan suatu kegiatan untuk menempatkan satu atau sekelompok fasilitas yang memiliki fungsi tertentu pada suatu lokasi (space) yang dimiliki oleh suatu sistem/organisasi dimana antara fasilitas-fasilitas tersebut akan terjadi berbagai interaksi kegiatan. Adapun tujuan perencanaan fasilitas adalah meminimasi total kebutuhan luas yang diperlukan untuk menempatkan fasilitas-fasilitas yang ada sesuai dengan tingkat kebutuhannya dan mengefisienkan space yang ada dengan cara meningkatkan pemanfaatan ruang yang tersedia. Perencanaan fasilitas dapat digunakan dalam merancang atau menentukan tata letak pada fasilitas-fasilitas pabrik, rumah sakit, sistem distribusi, fasilitas militer, supermarket, bank, maupun sekolah atau perguruan tinggi (Prasetyaningrum, 2009)

\section{METODE PENELITIAN}

Data atau informasi yang paling penting untuk dikumpulkan dan dikaji dalam penelitian ini sebagian besar berupa data kualitatif. Informasi tersebut akan digali dari berbagai sumber data. Sumber data yang akan dimanfaatkan dalam penelitian ini antara lain:

a. Informan atau narasumber, yang terdiri dari mahasiswa Universitas PGRI Adi Buana Surabaya yang dipilih secara acak sebanyak 10 orang untuk masing-masing program studi, hal ini dilakukan untuk mendapatkan informasi tentang kesan mahasiswa terhadap kondisi lingkungan fisik kampus Universitas PGRI Adi Buana Surabaya yang digunakan dan masukan berupa harapanharapan mahasiswa sebagai saran, dan pertimbangan dalam menyusun konsep perencanaan.

b. Data lingkungan fisik kampus Universitas PGRI Adi Buana Surabaya yang meliputi 2 (dua) kampus yaitu kampus I Ngagel Dadi dan kampus II Dukuh Menanggal. Adapun data yang menjadi variable dalam observasi adalah elemen pembentuk ruang lingkungan fisik kampus yaitu:

1. Uses (Pemanfaatan Ruang)

2. Building (Bangunan) 
3. Open Space (Ruang Terbuka)

4. Streets (Jalur Sirkulasi)

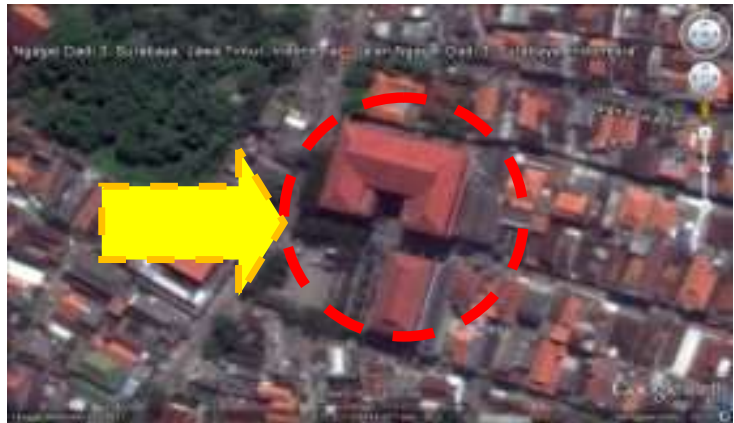

Gambar 1. Lokasi Gedung Kampus I Ngagel Dadi
5. Signage (Penandaan)

6. Lighting (Penerangan)

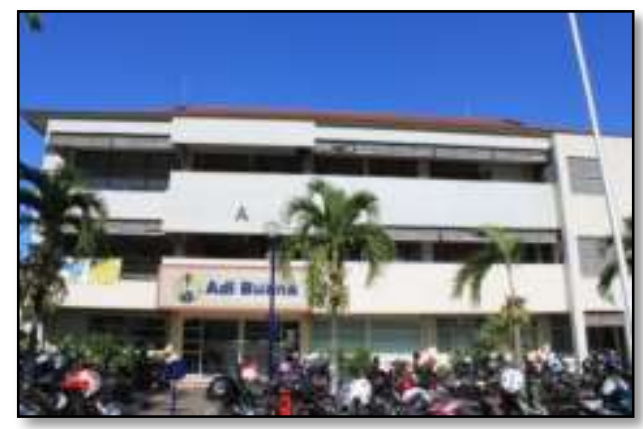

Gambar 2. Gedung Rektorat Kampus A

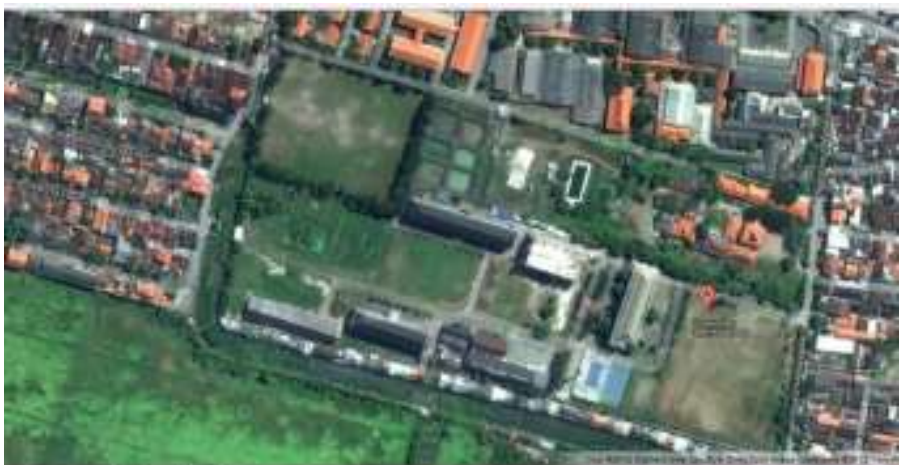

Gambar 3. Peta Lokasi Kampus B Universitas PGRI Adi Buana Surabaya

HASIL PENELITIAN DAN PEMBAHASAN

Berdasarkan gambaran fisik lingkungan dan fasilitas kampus Universitas PGRI Adi Buana Surabaya dan penelusuran melalui kuesioner yang disebar pada 20 Program Studi yang ada di Universitas PGRI Adi Buana didapat beberapa temuan yaitu:

a. Gambaran Persepsi Mahasiswa Terhadap Lingkungan Kampus Universitas PGRI Adi Buana Surabaya. Berdasarkan hasil analisis data yang didapat, terdapat beberapa hal yang menjadi gambaran dari persepsi mahasiswa terhadap lingkungan Kampus Universitas PGRI Adi Buana Surabaya yaitu:

\section{a) Uses / Fungsi}

Secara keseluruhan, dari segi fungsi bangunan dan pemanfaatan ruang dapat dikatakan mendapat persepsi yang cukup oleh mahasiswa, walau belum dapat dikatakan memiliki nilai yang cukup baik.
Fungsi-fungsi ruang yang ada banyak yang terkesan dipaksakan sehingga tidak memenuhi standard kebutuhan sebuah ruangan kelas terutama kapasitas ruang pada beberapa prodi yang memiliki jumlah mahasiswa yang cukup banyak.

Selanjutnya perlu pengkajian ulang dalam perencanaan pengembangan fasilitas kampus, hal ini diperlukan guna menghindari kesan pemanfaatan ruang-ruang sisa yang tidak sesuai letak terhadap fungsinya sehingga pemanfaatan ruang tidak bias dioptimalkan. Misalnya kantin yang berada dibelakan gedung dan lokasi yang 'terpencil' masih belum memenuhi standard kapasitas berdasarkan jumlah mahasiswa, sedangkan kantin bias berfungsi maksimal sebagai tempat bersosialisasi warga kampus dan lebih dari itu dapat dimanfaatkan sebagai sarana promosi apabila memilki kantin yang cukup representative untuk melayani umum, misalnya karyawan kantor yang berada disekitar Dukuh Menanggal. 


\section{b) Building / Bangunan}

Pemanfaatan dan bentuk bangunan fisik kampus Universitas PGRI Adi Buana Surabaya mendapatkan nilai yang cukup bagus dari mahasiswa, terutama bentuk desain bangunan yang ada di kampus B, sedangkan untuk kenyamanan dan keamanan mahasiswa menyatakan kondisi keamanan dan kenyamanannya buruk.

$\mathrm{Hal}$ ini terkait erat dengan fasilitas yang ada pada masing-masing kelas. Banyak muncul keluhan dari mahasiswa tentang kesenjangan fasilitas yang sangat berbeda pada masing-masing kelas. Hal ini tentunya sangat tidak diinginkan oleh pihak pengelola karena akan mepengaruhi reputasi pelayanan. Dengan karakter prodi yang berbeda, tentunya dituntut fasilitas yang berbeda pula pada masing-masing kelas maupun sarana penunjangnya. Permasalahan ini tentunya dapat diselesaikan dengan koordinasi yang baik antar pengelola fasilitas yang diberikan wewenang. Perlu ada pengecekan secara rutin pada masing-masing kelas dan sarana penunjangnya, bahkan perlu dibuatkan catatan dan jadual pengecekan ruang yang tersedia di masing-masing ruangan.

c) Open Space / Ruang Terbuka

Dalam menanggapi ketersediaan fasilitas ruang terbuka baik pemanfaatannya maupun desain ruang yang dibentuk, menunjukkan kondisi ruang terbuka yang ada saat ini masih belum memberikan manfaat yang optimal terhadap kegiatan mahasiswa. Ruang-ruang terbuka yang ada hanya digunakan sebagai lahan parkir, sedangkan untuk lahan parkir sendiri tidak memiliki fasilitas peneduh maupun batasan area parkir.

Kondisi ruang terbuka yang sangat minim di kampus A menyebabkan mahasiswa banyak yang mengisi waktu luangnya di area lobby gedung rektorat. Hal ini sangat kurang nyaman dipandang karena kebanyakan mahasiswa duduk di lantai sambil mengerjakan tugas mereka.

Lain halnya dengan kondisi ruang terbuka yang ada di kampus B yang cukup luas, ruang terbuka tidak dapat dimanfaatkan secara maksimal karena masih minimnya spot-spot atau peneduh yang dapat dijadikan tempat berkumpul mahasiswa baik berdiskusi atau hanya mengisi waktu luang mereka di kampus.

Dengan permasalahan yang ada, perlu adanya kreatifitas dalam menyediakan ruang terbuka bagi mahasiswa baik di kampus A maupun di kampus B. Ruang terbuka berupa taman atau sekedar peneduh di halaman kampus dapat dibuat di kampus A dengan memanfaatkan ruang-ruang sisa yang ada misalnya lahan disamping BAAK. Sedangkan untuk kampus B perlu penambahan beberapa gazebo sebagai spot-spot yang menyebar di beberapa area kampus.

\section{d) Streets / Jalur Sirkulasi}

Sebagai penyedia jasa pendidikan bagi masyarakat, tentunya pencapaian dan aksesibilitas baik menuju lokasi kampus maupun aksesibilitas didalam kampus sendiri sangat memegang peranan penting. Selain memberikan citra kesatuan antar bangunan, aksesibilitas juga merupakan salahsatu fasilitas kenyamanan bagi pengguna kampus.

Dari data yang didapat, baik dari segi pencapaian ke lokasi kampus, pencapaian ke masing-masing ruang didalam gedung, ketersediaan fasilitas pejalan kaki dan kendaraan mahasiswa menyatakan cukup baik kecuali untuk fasilitas pejalan kaki mahasiswa menyatakan buruk.

Kondisi ini tentunya dapat dilihat pada jalan dan jalur sirkulasi yang ada di kedua kampus yang tidak menyediakan fasilitas pejalan kaki berupa pedestrian maupun peneduh. Sehingga pada saat hujan warga kampus akan terkurung pada gedungnya masing-masing karena tidak adanya akses peneduh bagi pejalan kaki yang seharusnya disediakan yang menghubungkan antar bangunan dan fasilitas penunjang dalam satu lokasi.

e) Signage / Penandaan

Penandaan pada lahan sebuah kampus sangat diperlukan karena pengunjung atau pengguna kampus adalah masyarakat umum. Perlu juga diperhatikan bahwa penandaan sangat diperlukan terutama bagi pengunjung yang baru pertama sekali datang ke suatu lokasi. Selain itu, karena kedua kampus Universitas PGRI Adi Buana ( Kampus A dan Kampus B) memiliki beberapa gedung dalam satu lokasi maka penandaan sangat diperlukan untuk member penunjuk arah dan keberadaan ruang pada masingmasing bangunan.

Berdasarkan data yang didapat, keberadaan penandaan atau signage pada kampus A dan B masih kurang memadai. Namun sekarang sudah dimulai adanya 
penandaan dan arah terutama pada lokasi di kampus B Dukuh Menanggal yang areanya cukup luas.

\section{f) Lighting / Penerangan}

Dalam hal penerangan lampu atau cahaya, kedua kampus yang dimiliki Universitas PGRI Adi Buana Surabaya dirasakan sudah cukup memenuhi untuk kegiatan perkuliahan. Namun pada beberapa kelas penerangan ruangan kelas masih kurang karena jenis lampu yang digunakan masih menggunakan lampu dengan cahaya kuning yang kurang sesuai untuk kegiatan belajar seperti yang terdapat pada kelaskelas di gedung Teknik dan MIPA.

Selain itu, karena terdapat kelas perkuliahan di kedua kampus yang dilaksanakan pada malam hari tentunya penerangan area kampus juga sangat dibutuhkan. Hal ini lah yang masih kurang dirasakan terutama pada area luar di kampus B Dukuh Menanggal. Kondisi ruang luar yang kurang penerangannya akan mengurangi rasa nyaman dan aman bagi mahasiswa yang berkuliah malam hari, terutama bagi perempuan. Sehingga perlu penambahan lampu taman pada beberapa spot terutama disepanjang jalan menuju gedung perkuliahan dan spot light pada masing-masing gedung.

g) Ruang Favorit

Diperlukan ruangan-ruangan favorit bagi mahasiswa dimana mereka bisa nyaman melakukan kegiatan diluar jam perkuliahan. Hal ini sangat mendukung kegiatan berdiskusi mahasiswa dan membangkitkan rasa memilki mahasiswa terhadap almamaternya. Dengan demikian, diharapkan mahasiswa akan lebih kreatif dan produktif baik dibidang pendidikan maupun kegiatan kemahasiswaan untuk menciptakan atmosfer akademik yang lebih kondusif.

\section{DAFTAR PUSTAKA}

Gibson, James L., John M. Ivancevich dan James H. Donnely, Jr., 2002, Organisasi dan Manajemen: Perilaku, Struktur, Proses. Jakarta , Penerbit: Airlangga.

Halim, Dedy (2005) Psikologi Arsitektur, Pengantar Kajian Lintas Disiplin. Grasindo, Jakarta.

Miles, M.B. dan Huberman, A.M. 1992. Analisis Data Kualitatif: Buku Sumber Tentang MetodeMetode Baru. UIPress. Jakarta.

Moleong, Lexi J. Metodologi Penelitian Kualitatif (2000), P. T. Remaja Rosdakrya, Bandung

Prasetyaningrum, Indah Dwi ( 2009) Analisis Pengaruh Pembelajaran Dan Kualitas Pelayanan Terhadap Kepuasan Mahasiswa Dan Loyalitas Mahasiswa (Studi Kasus Pada UndarisUngaran)TESISS-2 Magister Manajemen Program Studi Magister Manajemen Universitas Diponegoro

Strange, C. Carney and Banning, J.H. , (2001) Educating by design: Creating Environments That Work, San Francisco: Josey-Bass.

RENCANA STRATEGIS Universitas PGRI Adi Buana Surabaya tahun 2008-2012

Kumpulan Instrumen Standar 5 Akreditasi Institusi Perguruan Tinggi Departemen Pendidikan Nasional,Badan Akreditasi Nasional Perguruan TinggiJakarta, 2007 